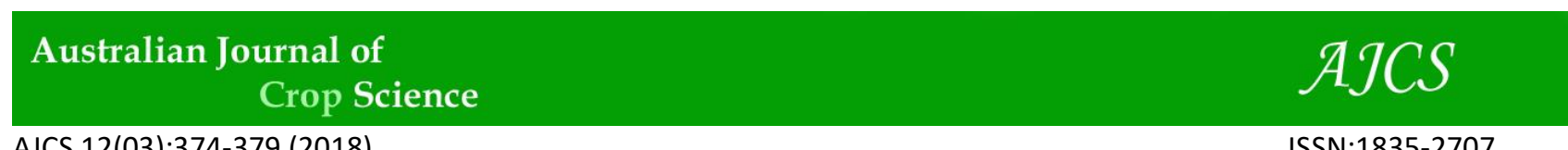

AJCS 12(03):374-379 (2018)

ISSN:1835-2707

doi: 10.21475/ajcs.18.12.03.pne744

\title{
Traction force demand of soybean planting in compacted Oxisol
}

\author{
Robson Gonçalves Trentin ${ }^{1}$, Alcir José Modolo ${ }^{1 *}$, Thiago de Oliveira Vargas ${ }^{1}$, José Ricardo da Rocha \\ Campos $^{1}$, Murilo Mesquita Baesso ${ }^{2}$, Emerson Trogello ${ }^{3}$, José Carlos Cazarotto Madaloz ${ }^{1}$
}

\author{
${ }^{1}$ Post-Graduation programme in Agronomy (Programa de Pós-graduação em Agronomia), Federal Technological \\ Unversity of Paraná (Universidade Tecnológica Federal do Paraná) - PPGAG/UTFPR, Pato Branco - PR, Brazil \\ ${ }^{2}$ Department of Biosystem Engineering, São Paulo University (Departamento de Engenharia Biossistemas, \\ Universidade de São Paulo) - FZEA/USP, Pirassununga - SP, Brazil \\ ${ }^{3}$ Goianian Federal Institute (Instituto Federal Goiano), IFGoiano, Morrinhos - GO, Brazil
}

\section{*Corresponding author: alcir@utfpr.edu.br}

\begin{abstract}
The heavy traffic of machinery and implements in no-tillage areas leads to surface compaction, especially when the managed soil contains high levels of moisture. This problem is one of the main causes of increased power demand in seeding operations. The aim of this paper was to assess the performance of two furrow opener mechanisms for planting soybean in clay soil with different levels of compaction and assess their relationship with traction demand. A random blocks experimental design with subdivided plots was used. The plots had four levels of soil compaction $\left(1.16,1.20,1.22\right.$, and $\left.1.26 \mathrm{Mg} \mathrm{m}^{-3}\right)$, and the subplots consisted of furrow openers (double-disc opener and shank-type opener) with four replications. Soybean sowing was carried out with a no-tillage seed with five lines. Seed deposition depth; cross-sectional area of mobilized soil; depth and width of the groove and the power demand measured by a load cell coupled between the tractor and the seeder were analyzed. The shank-type furrow opener increased the depth and width of the furrows, the planting depth and the disturbed area, and required greater power demand as the density of the soil increased. The contrary was observed with the double disc opener as this furrower presents low capability to reach deeper layers in compacted soil, as a result of its design characteristics.
\end{abstract}

Keywords: furrow openers; mobilized area; no-tillage; power demand; seeder.

Abbreviations: TDA_auxiliary front drive; FD_furrow depth; FW_furrow width; PDep_planting depth; DA_disturbed area; FDA mean force on the traction bar in relation to disturbed area.

Introduction

As a conservation management technique, direct seeding aims to maintain permanent soil cover and reduce tillage, disturbance, and erosion caused by water during the rainy season (Garcia and Righes, 2008). However, it also involves the intense traffic of machines and implements, causing soil compaction and a subsequent drop in production (Moraes et al., 2016; Naderi-Boldaji and Keller, 2016). Studies developed in Paraná affirm that around $45 \%$ of farm areas with clayey soil and cultivated with soybean/corn show levels of compaction in the $0.1-0.2 \mathrm{~m}$ layer, which is restrictive to root and aerial development of the plants (Franchini et al., 2011). Consequently, most farmers use shank-type furrow openers (Trogello et al., 2013) to prepare the soil and unpack the topsoil (Furlani et al., 2013). However, use of the chisel rod-like opener, or furrow opener, has become commonplace, even in areas where high levels of soil compaction are not observed. This leads to problems such as excessive tillage, and increased tensile strength requirements, greater fuel consumption and higher slip rates, thus increasing production costs (Levien et al., 2011; Santos et al., 2008).

The shank-type opener demands traction force for furrow lines between 2.0 and $3.8 \mathrm{kN}$, depending on the furrow depth, geometry and angle of the shank and the pointer with the soil, as well as water content of the soil (Conte et al., 2008). In the specific case of the soils in South-West Paraná, this power demand can be even greater since these soils were weathered from basalt with a high clay content, which therefore requires extra caution during motor mechanical operations to prevent excessive compaction.In a study on the power demand of a fertilizer and seed spreader equipped with shank-type opener on Ultisol, Mentges et al. (2010) found that increased soil compaction caused by the change of soil density from 1.55 to $1.71 \mathrm{Mg} \mathrm{m}^{-3}$ (up to 0.10 $m$ in depth) increased the power demand by around $22 \%$. However, in a study on no-till systems in Ultisol with two levels of traffic intensity in the same place, Rosa et al. (2012) did not find a significant difference in traction demand in a seeder-fertilizer equipped with chisel plough.

Evaluating operational parameters in a mechanized set, for rod and double-disc furrowers, on a Oxisol, Levien et al. (2011) found that in comparison to the double-disc furrow opener, the rod furrower caused an increase of $52 \%$ in soil mobilization, $32 \%$ in average traction power, and $60 \%$ in 
power peaks, besides a higher skidding index. The traction power values per seeding line were $2.55 \mathrm{kN}$ for rod and 1.93 $\mathrm{kN}$ for double-disc. The average power consumed on the traction bar with four seeding lines was $15.83 \mathrm{~kW}$ using rod, and $12.46 \mathrm{~kW}$ with double-disc.

The aim of this paper was to assess the performance of two furrow opener mechanisms for planting soybean in clay soil with different to levels of compaction and assess their relationship with the demand for traction.

\section{Results and Discussion}

\section{Seeding quality parameters}

The furrow depth created by the shank-type opener was $79 \%$ larger than the furrow depth created by the double disc opener (Table 1). This result proves that the shank-type opener has a higher soil breaking capacity, and a greater capacity to position the fertilizer under the seed. This is an important finding considering that fertilizers are generally salt-based and direct contact between the seed and fertilizer hinders the water absorption capacity of the seeds, especially at the start of soaking (Bansal et al., 1980, Moterle et al., 2009), which can interrupt the chain of events related to seed germination.

In a study conducted in Oxisoil compacted by animal grazing in a crop-livestock integration area, Andreolla and Gabriel Filho (2006) also observed that the shank-type opener created deeper furrows (around $0.12 \mathrm{~m}$ ) than the double disc opener (mean furrow depth of $0.05 \mathrm{~m}$ ).

The greater the depth created by the shank-type opener, the greater the depth of the furrow, which was also $13 \%$ wider than the furrow produced by the double disc opener, on average. However, furrow openers should preferably produce a smaller furrow width to prevent the incidence of invasive plants (Reis et al., 2006).

Higher planting depth values were also observed for the shank-type opener in comparison with the double disc opener. This result is justified by the greater soil depth capacity of the shank-type opener, thus providing greater planting depth. Similar results were obtained by Trogello et al. (2012) and Modolo et al. (2013) who worked in TypicHapludox compacted by a crop-livestock integration system. However, some authors obtained opposite results due to the more stable furrow walls provided by the double disc opener (Reis et al., 2004).

The average planting depths as a function of soil densities were between 0.04 and $0.054 \mathrm{~m}$ (Fig. 1A), which is generally suitable for planting soybean. This is a fundamental factor for the good emergence and initial establishment of the crop seedlings. When seeds planted at greater depths germinate, the seedlings have a thick layer of soil to explore until they reach the surface (Reis et al., 2004). Consequently, they take longer to surface and are thus exposed to attack from pests in the soil, hindering germination (Koakoski et al., 2007).

The disturbed area has a decreasing linear relationship with the density of the soil, (Fig. 1B), from 0.0052 to $0.0043 \mathrm{~m}^{2}$, with the density increasing from 1.16 to $1.26 \mathrm{Mg} \mathrm{m}^{-3}$. As the density increases, the furrow depth decreases and therefore reduces the disturbed soil area.

The shank-type furrow opener disturbed practically twice the area of the double disc opener. This result can be explained by the greater width and depth of the furrow obtained with the shank-type opener and shows that this method is an efficient alternative for breaking compacted surface layers. Francetto et al. (2015) also observed a greater disturbed area for the shank-type furrow opener, and an average of $31.25 \%$ compared with the double disctype opener. These authors attributed this result to the greater working depth used by the shank opener, to the unique actions of furrow opening mechanisms, and to the different dimensional characteristics of the elements that interfere in the shear stress, shearing, and compaction that these mechanisms cause in soil.

Modolo et al. (2013) studied the performance of furrow opening mechanisms in soils under different grazing intensities and found greater soil disturbance using the shank type opener in comparison with the double disc furrow opener, but did not observe any effects of grazing intensity on the disturbed area. Mion and Benez (2008) evaluated the effects of several opening tools in RodhicHapludoxand also found a larger disturbed area with the use of shank-type openers. However, Mion et al. (2009), in a study conducted in TypicHapludox, did not observe any differences between the shank-type opener and the double disc opener for a disturbed area with a mean density of 1.42 $\mathrm{Mg} \mathrm{m}^{-3}$ in the layer under $0.15 \mathrm{~m}$ using a no-tillage system.

\section{Energetic demand on the traction bar}

With the increased soil density, the mean force on the bar using the shank opener increased $19 \%$, while the mean force on the bar of the double disc opener dropped 9\% (Fig. 2A). These results are associated with the greater operational depth of the shank opener and the greater demand for traction as the soil density increases. Given the greater difficulty of the double disc opener to break the soil, it tends to create a shallower furrow as the compaction level increases, thus demanding less force on the traction bar (Conte et al., 2008).

In studies conducted in RhodicHapludox using a seeder consisting of four furrow lines and a shank type opener, Levien et al. (2011) and Seki et al. (2012) obtained tractive force values of 10.20 and $10.17 \mathrm{kN}$, while the double disc opener produced values of 7.72 and $4.31 \mathrm{kN}$, respectively.

Mean tractive force in relation to furrow depth has a linear relationship with increased soil density (Fig. 2B). Soil compaction affects traction demand, and $23 \%$ extra force is required to reach the same furrow depth when we compare the highest and the lowest levels of soil density.

A linear relationship was also observed between the specific force in relation to disturbed area and soil density (Fig. 2C). This behaviour agrees with the observed tractive force in relation to furrow depth and reveals that compacting generated by the tractor significantly increases the tractive force demanded by the seeder.

The force per disturbed area varied according to the furrow openers and a $12 \%$ drop in force was observed for the shank-type opener. Several authors observed similar results when comparing the efficiency of furrow opening mechanisms. Seki et al. (2012) obtained $5.78 \mathrm{~N} \mathrm{~cm}^{-2}$ in each planting line, when using a shank-type openeron Rhodic Hapludox, and $14.01 \mathrm{~N} \mathrm{~cm}^{-2}$ with the double disc opener. Levien et al. (2011), working with a four-row seeder, also in RhodicHapludox, obtained 119.2 and $137.2 \mathrm{~N} \mathrm{~cm}^{-2}$ for the shank and double disc openers, respectively. 
Table 1. Furrow depth (FD), furrow width (FW), planting depth (PDep), disturbed area (DA) and mean force on the traction bar in relation to disturbed area (FDA) according to the furrow openers.

\begin{tabular}{|c|c|c|c|c|c|}
\hline Openers & $\mathrm{FD}(\mathrm{m})$ & $\mathrm{FW}(\mathrm{m})$ & PDep (m) & $\mathrm{DA}\left(\mathrm{m}^{2}\right)$ & FDA $\left(\mathrm{kN} \mathrm{m}^{-2}\right)$ \\
\hline Disc & $0.048 b$ & $0.113 \mathrm{~b}$ & $0.041 \mathrm{~b}$ & $0.0031 \mathrm{~b}$ & $2093.33 \mathrm{a}$ \\
\hline Shank & $0.086 a$ & $0.128 a$ & $0.053 a$ & $0.0064 \mathrm{a}$ & $1839.24 \mathrm{~b}$ \\
\hline
\end{tabular}
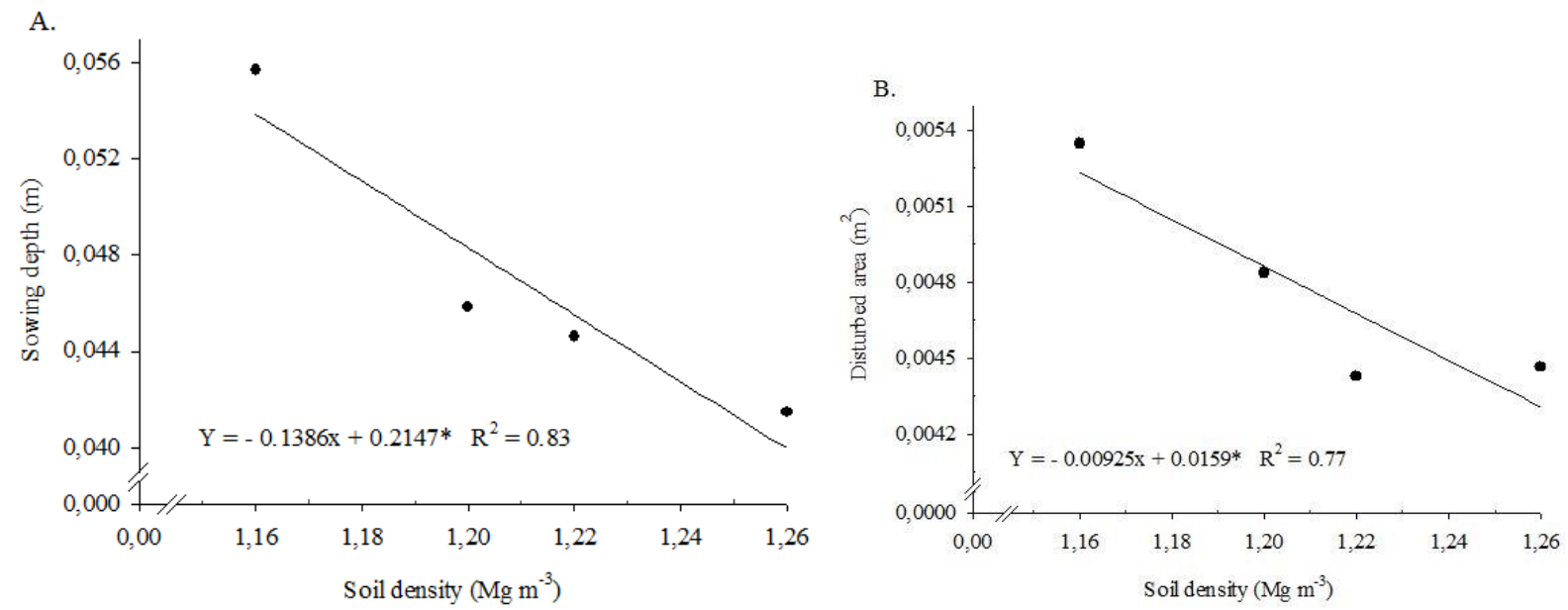

Fig 1. Soybean planting depth (A) and disturbed area (B) depending on the density of the soil.

A.

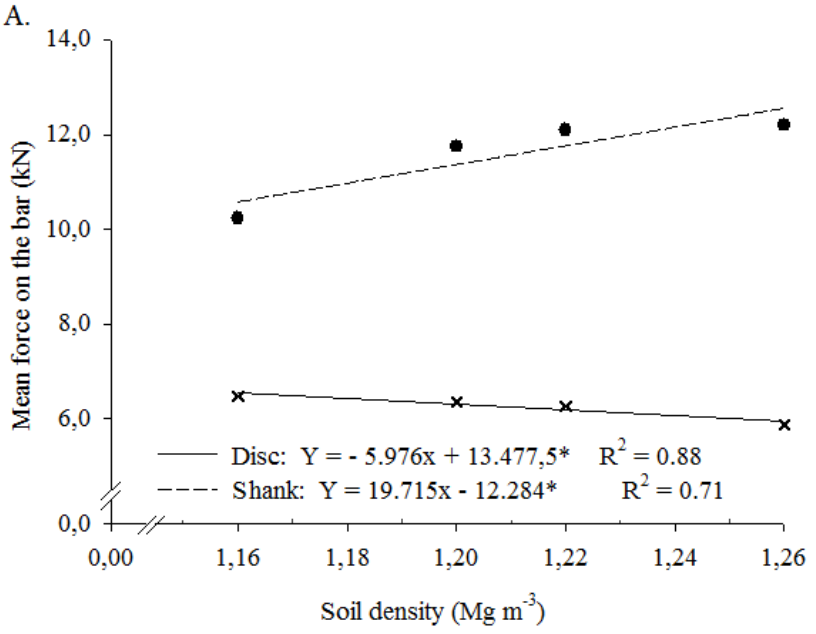

C.

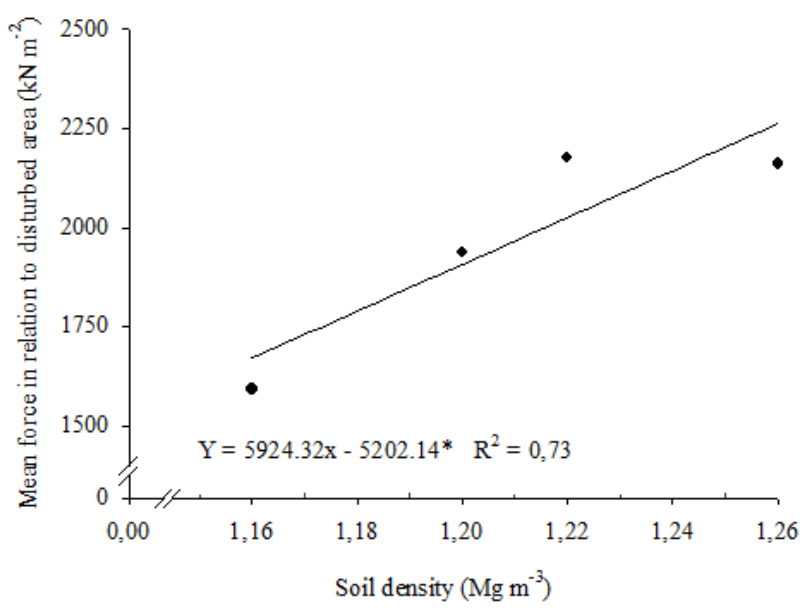

B.

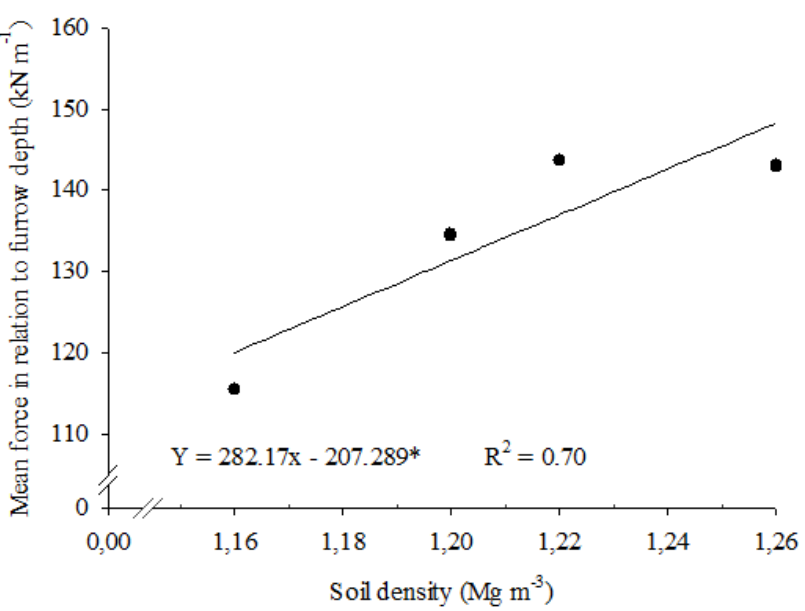

D.

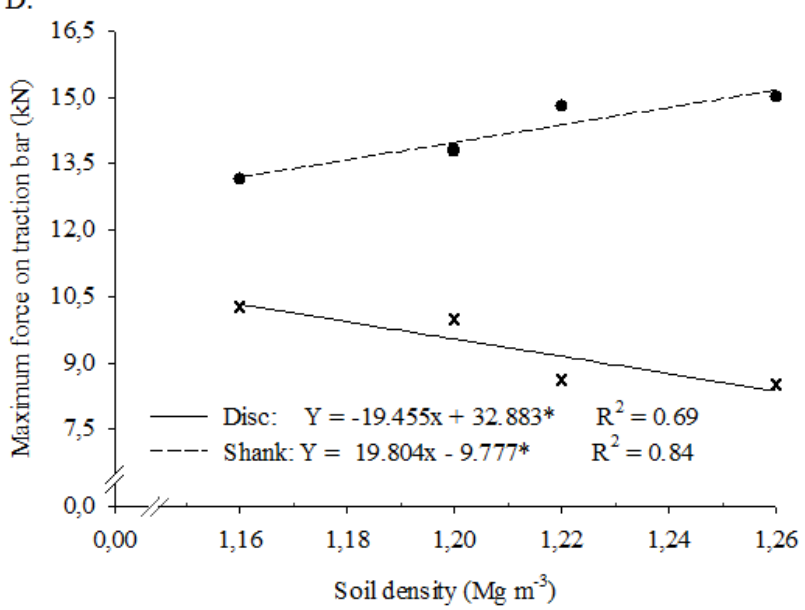

Fig 2. Demand for traction according to soil density: A) Mean force on the bar, B) mean force in relation to furrow depth, C) mean force in relation to disturbed area, and D) maximum force on traction bar. 
A.

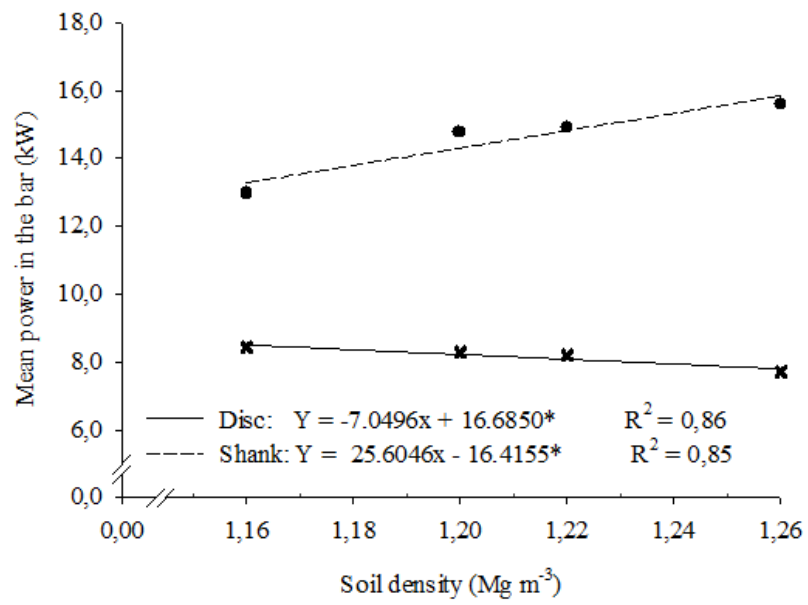

B.

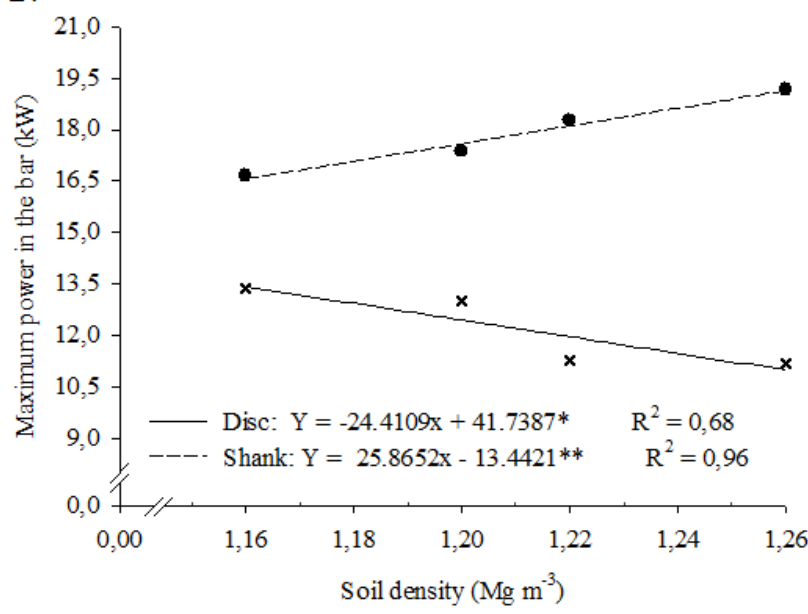

Fig 3. Power on bar in relation to soil density: A) mean power and B) maximum power.

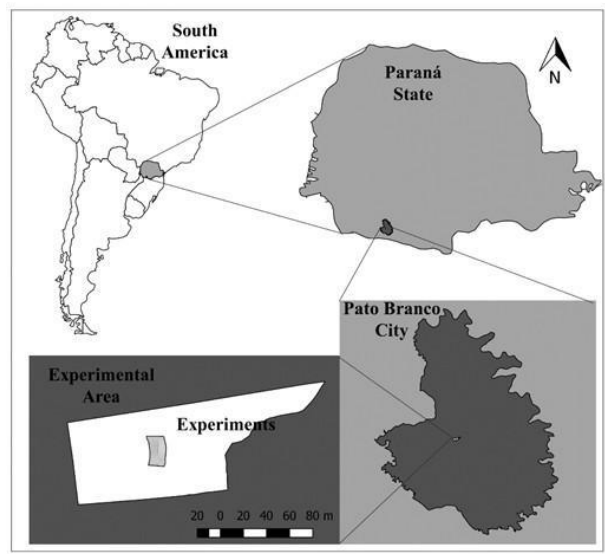

Fig 4. Geographical location of the study area.

Maximum force increased $15 \%$ using the shank-type opener, and decreased $19 \%$ using the double disc opener as the soil density increased from 1.16 to $1.26 \mathrm{Mg} \mathrm{m}^{-3}$ (Fig. 2D). Similar behaviour was observed for mean tractive force as the shank reached greater depths, thus disturbing a larger area of soil. On average, the maximum strength was approximately $23 \%$ greater than the mean force using the shank-type opener, and $50 \%$ greater using the double disc opener. Casão Júnior et al. (2000) observed a greater maximum force in relation to the mean force of between 11.9 and $32.0 \%$ using the shank-type opener.

When the soil density increased from 1.16 to $1.26 \mathrm{Mg} \mathrm{m}^{-3}$, the mean power of the traction bar increased $19 \%$ using the shank-type opener and dropped $8 \%$ using the double disc opener (Fig. 3A). Levien et al. (2011) used a four-row seeder in RhodicHapludox and observed a mean power on the bar of $15.83 \mathrm{~kW}$ using the shank-type opener and $12.46 \mathrm{~kW}$ using the double disc opener, which provided planting depths of 4.5 and $4.2 \mathrm{~cm}$, respectively, at an average working speed of $5.5 \mathrm{~km} \mathrm{~h}^{-1}$. Bonini et al. (2008) worked with different compaction levels in Typic Hapludox and a soil density that varied between 1.23 and $1.37 \mathrm{Mg} \mathrm{m}^{-3}$, and did not observe a significant difference in regard to the power in the traction bar per planting line in relation to the compaction levels. Maximum power required in the traction bar has a linear relationship with the density of the soil (Fig. $3 \mathrm{~B})$. Maximum force on the bar increased $15 \%$ with the shank-type opener and dropped $18 \%$ using the double disc opener as the soil density increased from 1.16 to $1.26 \mathrm{Mg} \mathrm{m}$ 3 . In general, maximum force using the shank-type opener was $23 \%$ greater than the mean power, and $50 \%$ greater than the mean power when using the double disc opener.

Using a four-row seeder in Rhodic Hapludox, Levien et al. (2011) obtained maximum power values of around 25.89 and $16.08 \mathrm{~kW}$ in planting depths of 4.5 and $4.2 \mathrm{~cm}$ using the shank-type opener and the double disc opener, respectively. CasãoJúnior et al. (2000) used a seven-row seederin soil with a density of $1.29 \mathrm{Mg} \mathrm{m}^{-3}$ and a shank-type opener that generated a furrow depth of approximately $10 \mathrm{~cm}$, and reached a peak power of 22 and $50 \mathrm{~kW}$ for work speeds of 4.5 and $8.0 \mathrm{~km} \mathrm{~h}^{-1}$, respectively.

\section{Materials and Methods}

\section{Study area description and treatments}

The experiment was conducted in Pato Branco city, Paraná Brazil (Fig. 4), in Typic Hapludox (Soil Survey Staff, 2014) with a very clayey texture ( $77.4 \%$ clay, $20.3 \%$ sand, $2.3 \%$ silt).

The treatments consisted of combining the de-phased double disc furrow opener and a shank-type furrow opener, a no-tillage fertilizer and seed spreader, and four induced soil compaction levels that were obtained by driving a tractor through the entire plot and compressing the soil along parallel strips. 


\section{Procedure for soil compaction induction}

The number of times the tractor passed along the strips varied according to the treatment, as follows: Level $0-$ no additional compaction; Level 1 - additional compaction, two tractor passes; Level 2 - additional compaction, four tractor passes; and Level 3 - additional compaction, six tractor passes, corresponding to the soil densities 1.16, 1.20, 1.22, and $1.26 \mathrm{Mg} \mathrm{m}^{-3}$, respectively.

The soil was compacted using a New Holland ${ }^{\circledR}$ tractor model TL75E 4 × 2 TDA (auxiliary front drive), with maximum allowable ballast weight $(4.630 \mathrm{~kg})$, Standard ${ }^{\circledR}$ front tires $12.4 \times 24$ and rear tires $18.4 \times 30$, and a Jacto ${ }^{\circledR}$ mounted sprayer $(250 \mathrm{~kg})$ stocked with 600 liters of water, totaling a mass of $5.480 \mathrm{~kg}$. The soil was compacted in October 2014, immediately after aperiod of rain, with a soil moisture content of $37.5 \%$.

\section{Arrangement and conduction of the experiment}

The experiment consisted of a split plot arrangement, in which the main plots were formed by four levels of soil density, and the subplots were formed by the two furrow openers, totalling eight treatments in a randomized block design with four replications. The area was divided into four random blocks, totalling 32 experimental units with an area of $75 \mathrm{~m}^{2}(3.75 \times 20 \mathrm{~m})$ each.

The soybean was planted on 22/10/2014 under a black oat (Avenastrigosa) straw coverage. A no-tillage fertilizer and seed spreader with a drag and a mechanical seed hopper was passed along five furrow lines spaced $0.45 \mathrm{~m}$ apart. Mean sowing speed was $4.6 \mathrm{~km} \mathrm{~h}^{-1}$ and the fertilizer seeder was used in second gear with reduced transmission at 2,000 rpm.

The fertilizer was deposited using a shank-type furrow opener with a $17.76 \mathrm{~mm}$ wide point, at a $20^{\circ}$ angle, and a height of $0.45 \mathrm{~m}$ or a furrow opener with a de-phased double disc $381 \mathrm{~mm}\left(15^{\prime \prime}\right)$ in diameter, depending on the treatment.

\section{Measurement of seed depth and area of disturbed soil}

The three central furrow lines in each experimental unit were used to establish the seed depth, based on 10 seeds per line after removal of the soil, and to measure the distance to the edge of the furrow.

The cross-sectional area of disturbed soilwas measured using a profilometer with vertical rulers graded in centimetres, transversally arranged every $2 \mathrm{~cm}$ in relation to the furrow line.The natural surface profile and final surface profile of the soil were established for each experimental unit. Collection occurred along two furrow lines with two replications in each line.

The depth and width of the fertilizer furrow was based on the greatest difference between the original surface and internal profiles of the soil in the seeding furrow (Araújo et al., 1999).

\section{Traction force measurement}

The demand for tractive force was measured using a load cell attached between the tractor and the seeder. The load cell was LíderBalanças ${ }^{\circledR}$ with a $50 \mathrm{kN}$ capacity and a sensitivity of $2 \mathrm{mV} \mathrm{V}^{-1}$. The Campbell Scientific ${ }^{\circledR}$ data acquisition system model CR800 was used to continuously monitor the traction bar force required by the fertilizer and seed spreader at a frequency of $10 \mathrm{~Hz}$ (ten readings per second).

Specific tractive forces were obtained for furrow depth and disturbed area using the ratio between mean force and furrow depth or disturbed area, respectively. Maximum tractive force corresponded to the highest tractive force value stored by the data acquisition system in each experimental plot. Mean power and maximum power required in the traction bar were determined by the product between mean average speed and average and maximum force, respectively.

\section{Statistical analysis}

The data were subjected to analysis of variance. In the case of significant differences $(p \leq 0.05)$, the averages of the furrow openers were compared using the Tukey test $(p \leq 0.05)$. Polynomial regression analysis was used for the soil compaction factor, represented by the variable soil density, and the models were selected according to the criterion of greater $R^{2}$ and the significance $(p \leq 0.05)$ of the parameters of the equation. All data were subjected to the Cocharan test $(p \leq 0.05)$ to check the homogeneity of the variances. For the inhomogeneous variables, the normality of the data was verified using the Lilliefors test ( $p \leq 0.05$ ), followed by data transformation into the square root of the variables that did not satisfy the assumptions of homogeneity and normality. SAEG ${ }^{\circledR}$ version 9.1 software was used to analyze the data (SAEG, 2007).

\section{Conclusion}

As the soil density increased, the planting depth and disturbed area decreased. The shank-type furrow opener proved more effective in breaking compacted layers in comparison with the double disc opener, and provided a greater furrow depth and width. As the density of the soil increased, the shank-type opener required greater power and force to break the soil, while the reverse effect was observed for the double disc opener.

\section{Acknowledgements}

The authors would like to thank the CNPq (Research Productivity), and the Araucaria Foundation for the financial support.

\section{References}

Andreolla VRM, Gabriel Filho A (2006) Demanda de potência de umasemeadora com doistipos de sulcadorese máreascom pactadaspelopisoteio de animais no sistemaintegraçãolavoura-pecuária.Eng Agric. 26:768-776.

Araújo AG, CasãoJúnior R, Ralisch R, Siqueira R (1999) Mobilização de solo e emergência de plant asnasemeaduradireta de soja (Glycinemax L.) e milho (Zeamays L.) em solos argilosos. Eng Agric. 19:226-237.

Bansal RP, Bhati PR, Sen DN (1980) Differential specificity in water inhibition of Indian arid zone.Biol Plantarum. 22:327-331. 
Bonini AK, Filho AG, Secco D, Souza RF, Tavares C (2008) Atributosfísicos e requerimento de potência de umasemeadora-adubadoraem um Latossolo sob estados de compactação. EngAgric. 28:136-144.

CasãoJúnior R, Araújo AG de, Ralisch R (2000) Desempenho da semeadora-adubadora MAGNUM 2850 emplantiodireto no basaltoparanaense. PesquiAgropecu Bras. 35:523-532.

Conte O, Levien R, Trein CR, Mazurana M, Debiasi H (2008) Resistênciamecânica do solo e força de traçãoem hastes sulcadoras de semeadoras-adubadorasemsistema de integraçãolavoura-pecuária. Eng Agric. 28:730-739.

Francetto TR, Alonço A dos S, Bellé MP, Franck CJ, Carpes DP (2015) Comportamentooperacional de associações entre sulcadores e discos de corteparasistema de semeaduradireta. Eng Agric. 35:542-554.

Franchini JC, Costa JM, Debiasi H, Torres E (2011) Importância da rotação de culturaspara a produção agrícolasustentável no Paraná. Londrina: Embrapa Soja, $52 \mathrm{p}$.

Furlani CEA, Canova R, Cavichioli FA, Bertonha RS, Silva RP da (2013) Demandaener géticaporsemeadoraadubadoraemfunção da haste sulcadoranasemeadura do milho. Rev Ceres. 60:885-889.

Garcia SM, Righes AA (2008) Vertical mulching e manejo da águaemsemeaduradireta. RevBrasCienc Solo. 32:833-842.

Koakoski A, Souza CMA de, Rafull LZL, Souza LCF de, Reis EF dos (2007) Desempenho de semeadoraadubadorautilizando-se doismecanismosrompedores e trêspressões da rodacompactadora. PesquiAgropecu Bras. 42:725-731.

Levien R, Furlani CEA, Gamero CA, Conte O, Cavichioli FA (2011) Semeaduradireta de milho com doistipos de sulcadores de adubo, emnível e no sentido do declive do terreno. Cienc Rural. 41:996-1002.

Mentges MI, Reichert JM, Rosa DP da, Vieira DA, Rosa VT da, Reinert DJ (2010) Propriedadesfísico-hídricas do solo e demandaenergética de haste escarificadoraem Argissolo compactado. PesquiAgropecu Bras. 45:315-321.

Mion RL, Benez SH (2008) Esforçosem ferramentas rompedoras de solo de semeadoras de plantiodireto. CiencAgrotec. 32:1594-1600.

Mion RL, Benez SH, Viliotti CA, Moreira JB, Salvador N (2009) Análise tridimensional de esforço semelemento srompedores de semeadoras de plantiodireto. Cienc Rural. 39:1414-1419.
Modolo AJ, Franchin MF, Trogello E, Adami PF, Scarsi M, Carnieletto R (2013) Semeadura de milho com dois mecanismossulcadores sob diferentesintensidades de pastejo. Eng Agric. 33:1200-1209.

Moraes TM, Debiasi H, Carlesso R, Franchini JC, Silva VR, Luz FB (2016) Soil physical quality on tillage and cropping systems after two decades in the subtropical region of Brazil. Soil Till Res. 155:351-362.

Moterle LM, Santos RF dos, Braccini A de L, Scapim CA, Lana $M$ do C (2009) Influência da adubação com fósforo e potássionaemergência das plântulas e produtividade da cultura da soja. Rev Cienc Agron. 40:256-265.

Naderi-Boldaji M, Keller T (2016) Degree of soil compactness is highly correlated with soil physical quality index S. Soil Till Res. 159:41-46.

Reis EF dos, Fernandes HC, Schaefer CEGR, Araújo EF (2004) Avaliação de mecanismosrompedores e compact adoresem semeaduradireta. EngenharianaAgricultura. 12:212-221.

Reis EF dos, Schaefer CEGR, Fernandes HC, Naime J de M, Araújo EF (2006) Densidade do solo no ambiente solosemente e velocidade de emergênciaemsistema de semeadura de milho. Rev Bras Cienc Solo. 30:777-785.

Rosa DP da, Reichert JM, Mentges MI, Rosa VT da, Vieira DA, Reinert DJ (2012) Demanda de tração e propriedadesfísicas de um Argissoloemdiferentesmanejos e intensidades de tráfego. PesquiAgropecu Bras. 47:118126.

SAEG SistemaparaAnáliseEstatística (2007) Versão 9.1, Viçosa: Fundação Arthur Bernardes.

Santos AP, Volpato CES, Tourino MCC (2008) Desempenho de trêssemeadoras-adubadoras de plantiodiretopara a culturadomilho. Cienc Agrotec. 32: 540-546.

Seki AS, Benez SH, Silva PRA (2012) Desempenhooperacional de semeadora e produtividade do milhoemplantiodireto e cultivomínimo.Energiana Agricultura. 27:1-18.

Soil Survey Staff. Keys to soil taxonomy. 12. ed. Washington: U. S. Department of Agriculture. Natural Resources Conservation Service, 2014. 372p.

Trogello E, Modolo AJ, Carnieletto R, Kolling EM, Scarsi M, Sgarbossa M (2012) Desenvolvimentoinicial e produtividade da cultura do milho no sistema de integraçãolavoura-pecuária. Rev Ceres. 59:286-291.

Trogello E, Modolo AJ, Scarsi M, Dallacort R (2013) Manejos de cobertura, mecanismossulcadores e velocidades de operaçãosobre a semeaduradireta da cultura do milho. Bragantia. 72:101-109. 